\title{
Adaptive Time Varying Autopilot Design
}

\author{
Nataša Vlahović ${ }^{1)}$ \\ Stevica Graovac ${ }^{2)}$ \\ Miloš Pavić ${ }^{1)}$ \\ Milan Ignjatović1
}

\begin{abstract}
Missile autopilots represent devices for precise following of a target that missiles are sent to intercept. Commands that need to be executed are forwarded to the autopilot in order to achieve demanded performance. Usually, in representation of an autopilot and its performance, a model with constant parameters is used. Constant autopilot parameters and missile coefficients are calculated from time varying values. Model with constant parameters is shown in this paper, as well as the results obtained from this model. These values are then used as the initial ones for calculations in time varying pitch autopilot model design based on gain-scheduling. It is shown how the coupling with other axis such as yaw is cancelled by using time varying parameters. All the models are implemented in Matlab and Simulink toolbox.
\end{abstract}

Key words: autopilot, design, adaptive device, adaptive control, pitch, time varying parameters, coupling.

$\mathrm{I}_{\mathrm{T}}^{\mathrm{N}}$ this paper, a tactical missile autopilot design is shown. The purpose of a tactical missile is to intercept targets, and since tactical missile autopilots are part of the larger system, they must contribute to that goal. The process by which a missile executes an intercept is by first sensing the target, and then the target information is used to generate guidance commands. If the guidance commands are followed precisely, the missile will intercept the target. The problem is to follow them with precision, and this is where the autopilot comes in. The missile autopilot receives guidance commands and produces control deflections to move the missile in a manner consistent with completing the intercept [1].

Missile and its behavior are described with equations of motion that are nonlinear and time varying. In this paper, a procedure that it is used is linearization of these equations for various flight conditions and then autopilot design is performed with linearized, but time varying parameters.

As general design of an autopilot for many missiles is performed assuming the independence of roll, pitch and yaw channels, this simplified model can cause problems in practice. One of the reasons that can cause problems is coupling between pitch, yaw and roll axes, which is nowadays very popular topic [2]. The autopilot design approach is described through phases, from simple model with constant coefficients and parameters through time varying model with one optimal value for the adjustable parameters. At the end, an adaptive autopilot design is described, with four time ranges for the adjustable parameters. All design and simulations are realized in Matlab and Simulink software.

\section{Autopilot design}

An autopilot represents a system for automatic control and stabilization of a moving object. One of possible realizations of a missile lateral autopilot is normal acceleration control with accelerometer and gyroscope, which is shown in this paper [3].
An autopilot is a closed loop system and it is an inner loop inside the main guidance loop. Not all missile systems require an autopilot, but for a more precise system it is a necessity. A missile that carries accelerometers and/or gyroscopes in order to provide additional feedback into the missile servos to modify the missile motion has autopilot in missile control system. Autopilots control the motion in the pitch and yaw planes - they are called lateral autopilots, or they control the motion about longitudinal axis - roll autopilots. Autopilot's main tasks are: to increase the system natural frequency, to increase the system natural damping ratio, to reduce the cross-coupling between axes, to assist in gathering. [4].

\section{Constant parameter autopilot design}

Autopilot model is based on linearized equations of motion, and from this model we obtain missile transfer function aerodynamic parameters for the design procedure. In this paper, a procedure for the design of a pitch autopilot is represented. The design procedure is similar for other axes.

Basic parameters of the missile motion in one plane, in this case vertical plane are shown in Fig.1.

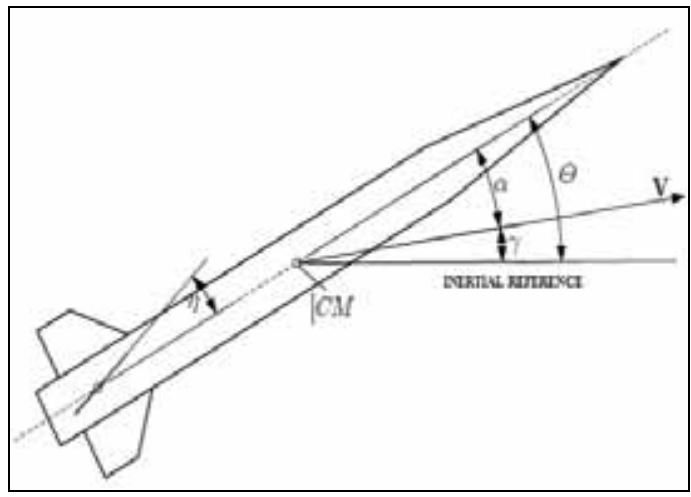

Figure 1. Basic parameters of a missile motion

\footnotetext{
1) Military Technical Institute (VTI), Ratka Resanovića 1, 11132 Belgrade, SERBIA

2) University of Belgrade, Faculty of Electrical Engineering, Kralja Aleksandra 73, 11000 Belgrade, SERBIA

Correspondence to: Nataša Vlahović, e-mail: natasha.kljajic@yahoo.com
} 
Using the small perturbation theory, the transfer functions are developed. The pitch rate transfer function is:

$$
\frac{\Delta q}{\Delta \eta_{p}}(s)=\frac{\omega_{n}^{2} E_{q}\left(r_{q} g+1\right)}{g^{2}+2 \xi_{n} \omega_{n} s+\omega_{n}^{2}}
$$

Where parameters are calculated according to equations:

$$
\begin{gathered}
2 \zeta_{n} \omega_{n}=-\left(m_{Q}+z_{w}\right) \\
\omega_{n}^{2}=-\left(m_{w} V=z_{w} m_{q}\right) \\
K_{q}=\frac{z_{n} m_{n x}-z_{w} m_{n}}{m_{q} z_{w}-m_{w} V} \\
T_{q}=\frac{m_{n}}{z_{n} m_{w}-z_{w} m_{n}}
\end{gathered}
$$

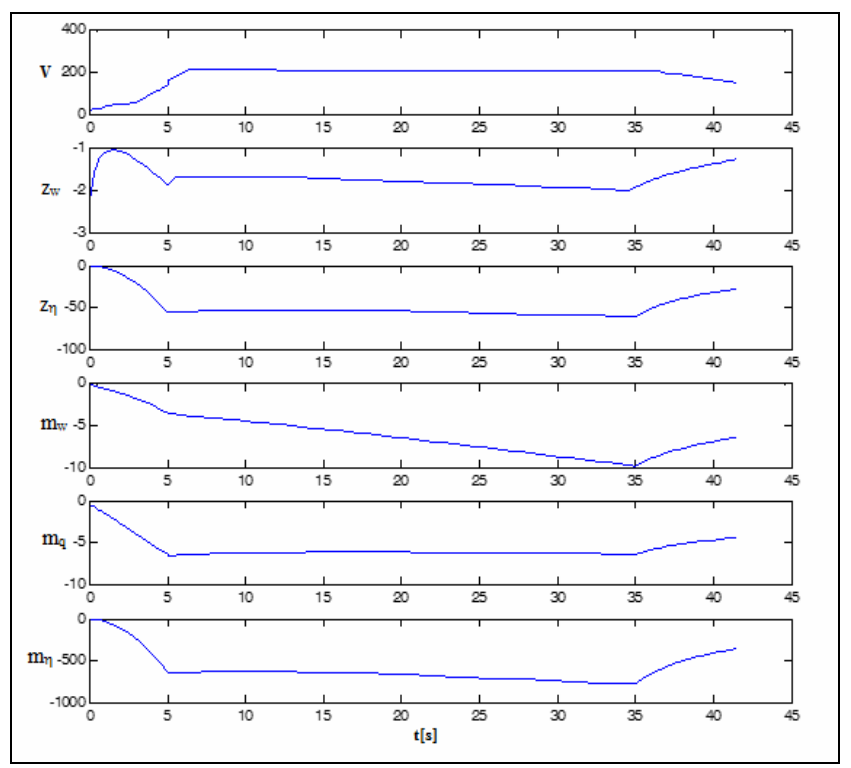

Figure 2. Missile flight parameter change over time

First step represents plotting the parameters that are used in transfer function in time, in order to see how these time variable parameters change in time. Aerodynamic parameters are calculated for tactical anti-tank missile with almost constant velocity and aerodynamic parameters. In Fig. 2 all parameters needed for autopilot's parameters calculations are shown, as well as $V$ - missile velocity change over time for comparison.

As it can be seen in Fig.2, flight parameters over time are almost constant from 7 th to 35 th second. For constant parameter autopilot design for each parameter, mean value is calculated, as well as transfer function with mean value of parameters.

Aerodynamic transfer functions that are important for autopilot design are shown in Picture 3, where the model used in design is represented. The presented model is $3^{\text {rd }}$ order model, which takes into account that some dynamics (such as accelerometer, gyro, actuator, structural filter) are relatively fast, thus not modelled. As it can be seen from a model, there are three important aerodynamic transfer functions. The first one is pitch rate transfer function in the inner loop, and the second one is pitch normal acceleration transfer function. As for the pitch acceleration transfer function in outer loop, measured by accelerometer $\frac{\Delta a_{n}^{\prime}}{\Delta \eta}$, it is taken to be the same as pitch acceleration transfer function $\frac{\Delta a_{n}}{\Delta \eta}$ for the simplicity of calculations.

So, next aerodynamic transfer function that is important in autopilot design is acceleration transfer function $\frac{\Delta a_{n}}{\Delta \eta}$ :

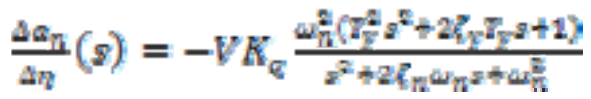

Parameters are calculated according to equations:

$$
\begin{aligned}
& \omega_{n}^{2}=-\left(m_{w} V-z_{w} m_{q}\right) \\
& 2 \zeta_{n} w_{n}=-\left(m_{q}+z_{w}\right) \\
& K_{q}=\frac{z_{n} m_{w}-z_{w r} m_{n}}{m_{q} z_{w}-m_{w} v} \\
& T_{q}=\frac{m_{n}}{z_{n} m_{\underline{u}}-z_{\underline{k}} m_{m}} \\
& T_{Y}^{2}=-\frac{z_{\eta}}{W\left(z_{\eta} m_{w}-z_{w} m_{\eta}\right)} \\
& 2 Z_{Y} T_{Y}=-\frac{m_{q} z_{\eta}}{v\left(x_{\eta} m_{u}-z_{u s} m_{\eta_{k}}\right)} \\
& T_{n}^{2}=\frac{1}{\omega_{n}^{2}}=\frac{1}{-\left(m_{W} V-z_{w} m_{Q}\right)} \\
& 2 Z_{n} T_{n}=\frac{2 Z_{n} \omega_{n}}{\omega_{n}^{2}}=\frac{m_{q}+w_{w s}}{m_{w} V=z_{w} m_{q}}
\end{aligned}
$$

For this transfer function calculation it is also necessary to see over time change of the parameters. After plotting the parameters over time, the results show that also these parameters are nearly constant in time range from 7 th to 35 th second. Thus, mean value of every parameter is calculated in order to calculate transfer function.

Since autopilot represents system for automatic control and motion stabilization of a guided object, there are few design solutions. One of possible realizations is normal acceleration control system with accelerometer and rate gyroscope. In order to simplify the process for the initial calculations, 3rd order model is used (Fig.3).

All other necessary parameters for autopilot design are given below:

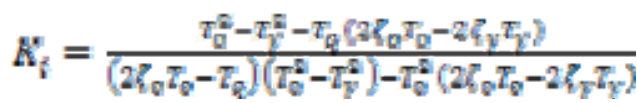

$$
\begin{aligned}
& K_{a Q}=\frac{1}{V} \frac{T_{0}^{2}-\frac{T_{Q}}{K_{l}}}{T_{\psi}^{2}=\tau_{Q}^{2}} \\
& K_{p}=\frac{B_{R}}{-E_{R} R_{4}\left(1+K_{a v} V^{7}\right)}
\end{aligned}
$$




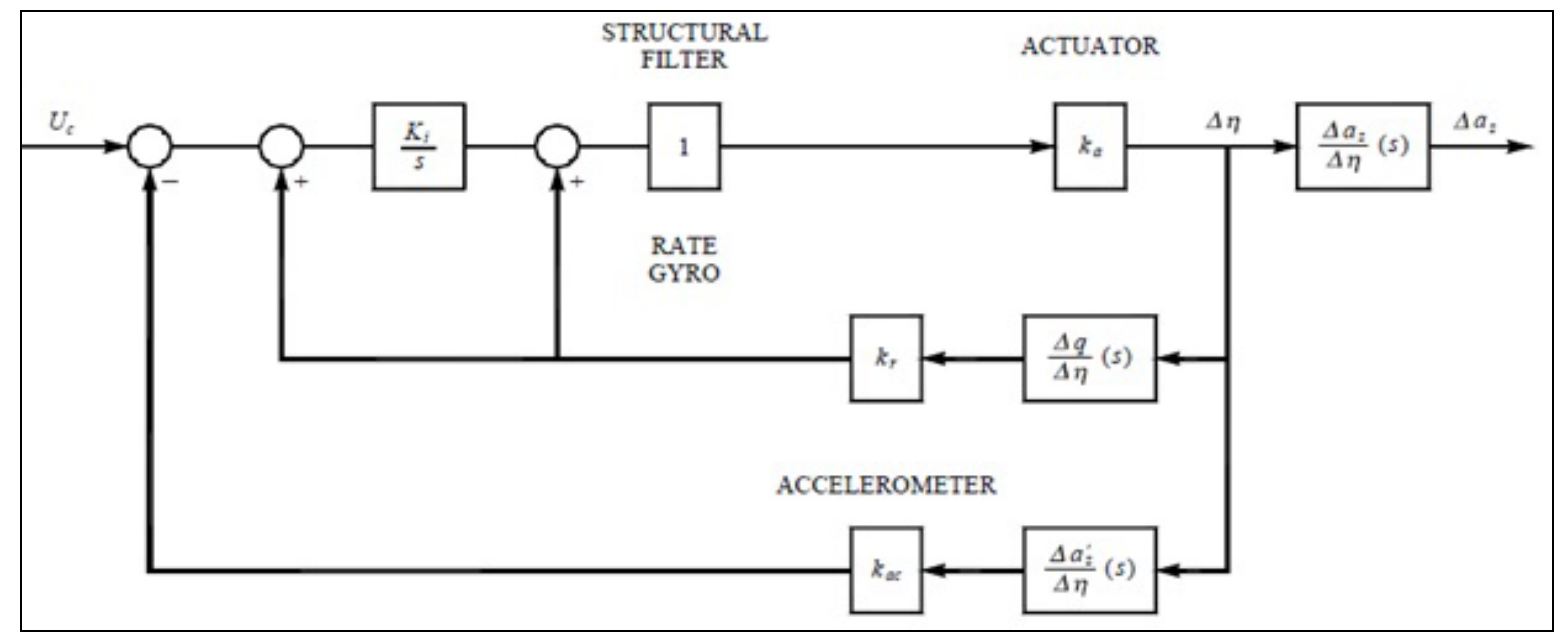

Figure 3. Autopilot design $-3^{\text {rd }}$ order model

$$
\begin{aligned}
& T_{0}=T_{e} \sqrt{\omega_{e} \tau_{e}} \\
& 2 \zeta_{0} T_{0}=2 \zeta_{e} T_{e}+\tau_{e}\left[1-\left(\frac{T_{e}}{\tau_{n}}\right)^{2}\right] \\
& T_{v}=\frac{2 \xi_{q} T_{\varepsilon}}{\left(\frac{2 K_{n}}{T_{n} \omega_{\varepsilon}}+1\right) \omega_{\varepsilon} \tau_{\varepsilon}-1} \\
& K_{0}=\frac{\tau_{i}^{\pi}}{T_{0}^{2}} \omega_{e}
\end{aligned}
$$

Parameters $K_{i}, K_{r}, K_{a c}$ represent adjustable parameters that need to be adjusted in order to have desired system response, defined by desired values of $\tau_{e}, \omega_{e}, \xi_{e}$ parameters [5].

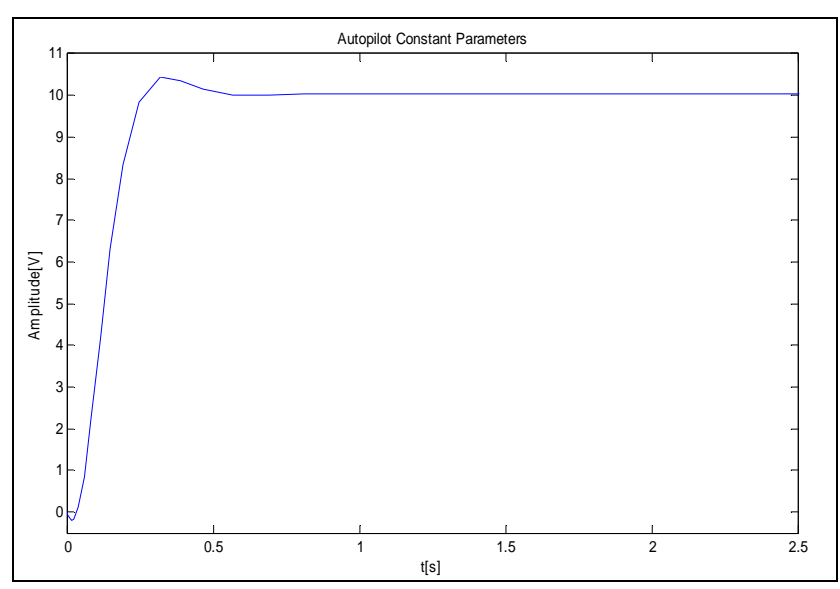

Figure 4. Constant parameters autopilot step response

After parameter calculation, next step is Simulink model design, based on 3rd order model with mean value of transfer functions parameters. This step is important for the autopilot designer in order to observe basic system behavior, so that more complex model can be designed more easily, as well as to have some initial knowledge about the system. System step response is shown in Fig.4.

In this case, as well as for other plots with autopilot response, the observed response represents normal acceleration response, measured with simulated accelerometer.

\section{Time varying autopilot design}

Since constant parameter model shows some basic behavior of the system, but it is not accurate enough, next design step is time varying autopilot design, with transfer functions parameters that are dynamically changed over time. In this section, a procedure for time varying autopilot design in Matlab and Simulink is described. The desired transfer functions have to be represented in canonic form, in order to accomplish time varying design in Simulink. Detailed procedure for canonic form calculation is described in [6].

With transfer functions transformed into canonic representation, it is now possible to plot the response with dynamic parameters that vary in time, which is certainly more accurate system's model. In this step of autopilot design, adjustable parameters have only one value during the time interval, and it is set to the value that insures the best possible system response. For the pulse input signal, system response is shown in Fig.5.

In Fig. 6 is shown transfer function on the left side, and its canonic representation on the right side.

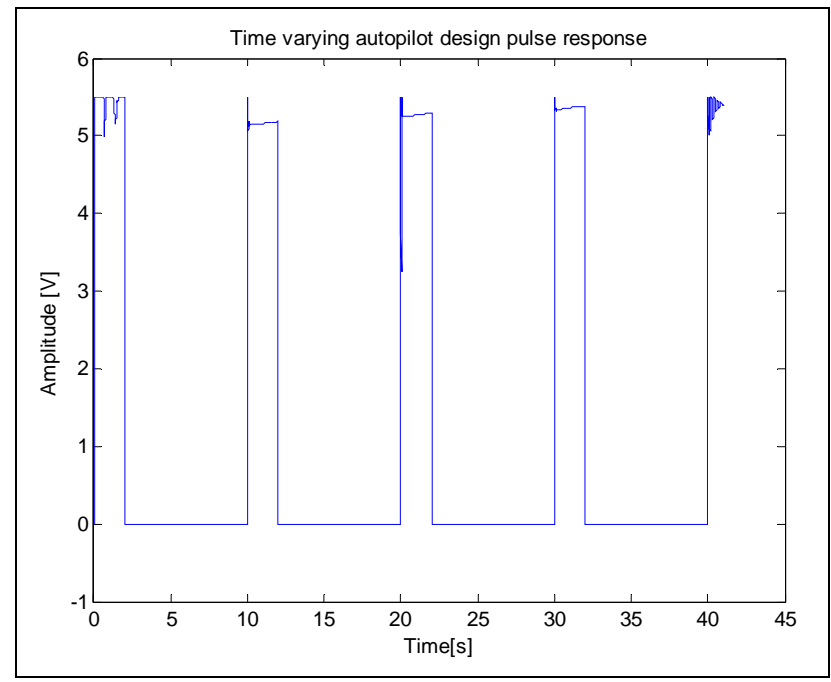

Figure 5. System response time varying autopilot design

From the time varying autopilot design with one value for the adjustable parameters response plot it can be seen that for the time interval with nearly constant flight parameters the response is above the ideal stationary state value, but not much. It is also visible that for the first and last part of the flight, where flight parameters change significantly, and the response is very unstable with visible oscillations, which was expected, but it is not desirable behaviour of a system. In next step, the idea is to set more values for the adjustable parameters in order to improve the performance of the system. 


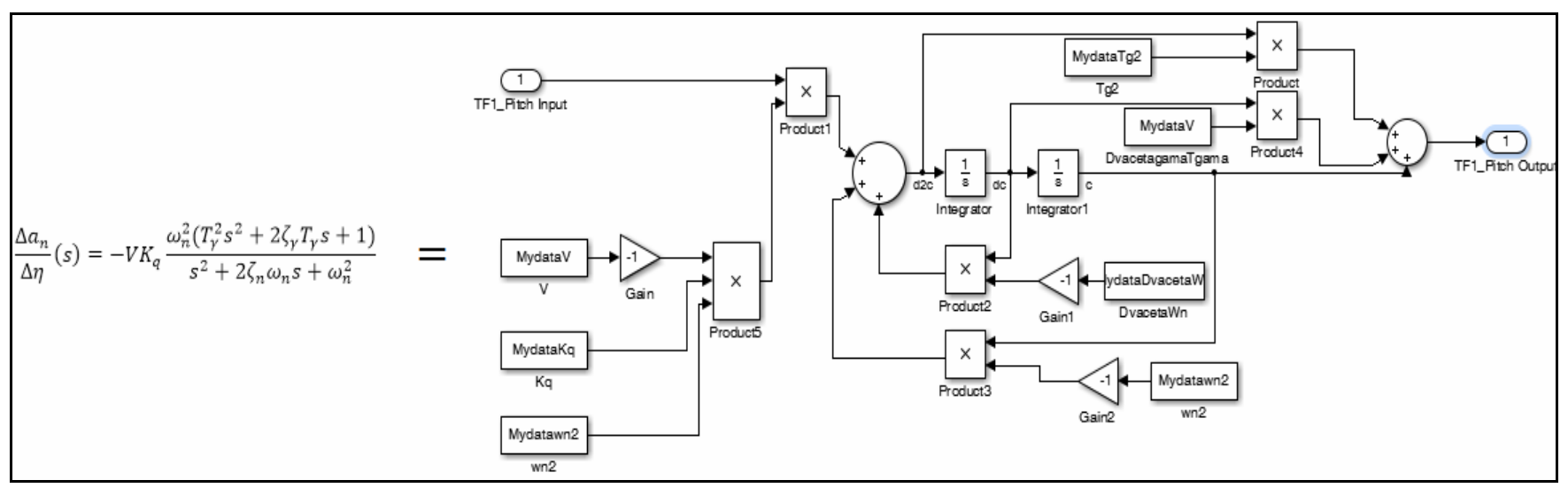

Figure 6. Canonic representation of transfer function

\section{Adaptive gain scheduling autopilot design}

In this chapter, an adaptive autopilot design is explained. For each missile flight phase, different values of adjustable parameters are set in a way that insures best possible response. Since the same input signal is used, the results are compared to the results obtained with autopilot design from the previous step that has one value for each parameter (Fig.8).

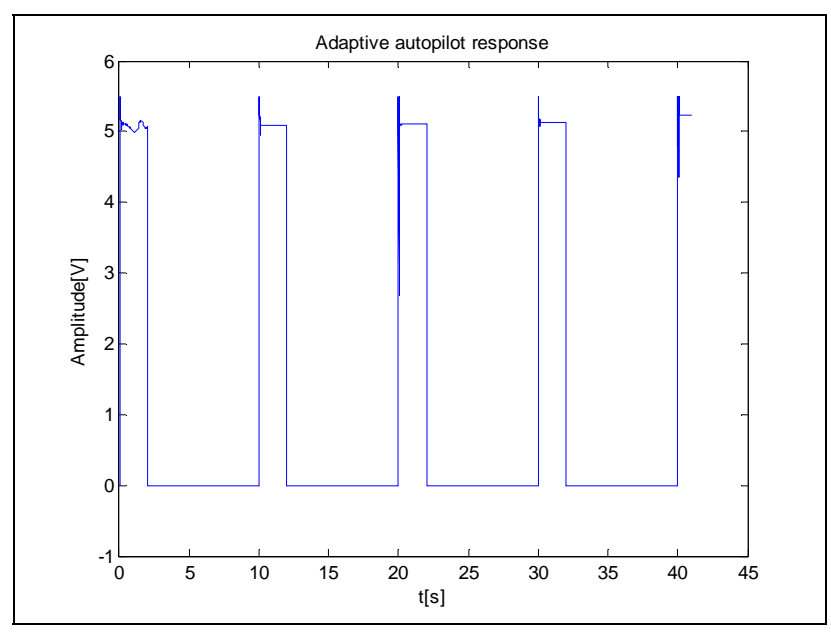

Figure 7. System response gain scheduling autopilot

Autopilot's gain scheduled parameters are derived in terms of functions of the designed system parameters with the objective of the control to achieve tracking of a commanded acceleration with stability and precision. So, the goal is to obtain the best possible commanded acceleration tracking.

Table 1. Adjustable parameters values

\begin{tabular}{|c|c|c||}
\hline \hline Period & $\begin{array}{c}\text { Time range }[\mathrm{s}] \\
\text { V value }\end{array}$ & Parameters values \\
\hline \hline I & {$[0,3]$} & $\tau_{\mathrm{e}}=0.0105, \omega_{\mathrm{e}}=85, \xi_{\mathrm{e}}=0.7$ \\
\hline II & $(3,6]$ & $\tau_{\mathrm{e}}=0.0069, \omega_{\mathrm{e}}=120, \xi_{\mathrm{e}}=0.7$ \\
\hline III & $(6,7]$ & $\tau_{\mathrm{e}}=0.0105, \omega_{\mathrm{e}}=85, \xi_{\mathrm{e}}=0.7$ \\
\hline IV & $(7,35]$ & $\tau_{\mathrm{e}}=0.0073, \omega_{\mathrm{e}}=118, \xi_{\mathrm{e}}=0.7$ \\
\hline V & $(35,41]$ & $\tau_{\mathrm{e}}=0.008, \omega_{\mathrm{e}}=115, \xi_{\mathrm{e}}=0.7$ \\
\hline
\end{tabular}

In Table 1 desired performance values for different time ranges are shown. For these desired values, during the operating time, adjustable parameter values are calculated in order to be used in different operating ranges. Since unstable periods with oscillations in response are present in periods with the most significant changes in dynamic missile parameters, which are in the beginning of a flight and at the end, while the part with almost constant parameters is from around $7^{\text {th }}$ to $35^{\text {th }}$ second, values for adaptive parameters are defined accordingly. That is why there is only one parameter value for the whole constant part of flight path, and more values for the dynamic part in the first part of the flight path where parameters should follow the change in dynamic missile coefficients.

As we can see from the response plot, now for stationary state the result is better. In first and last part of time interval, where flight parameters are very changeable, the response is more stable than in the case of just one value for adjustable gains.

\section{Simulation and results}

In last few sections, an approach for gain scheduling autopilot design was described. Now, the results that are obtained from non-adaptive and adaptive design will be compared, in the case of a present disturbance.

Since missile autopilots also perform a task of reducing cross-coupling between axes, an influence of a disturbance of this type is examined. The autopilot design is described for a missile with slow rotation, and in the observed channel - pitch channel, exists a parasite signal, command from other channel - yaw channel. Since the realized design is for pitch autopilot, now yaw autopilot (which is the same as pitch autopilot) signal will represent the disturbance coupled on pitch signal. Obviously, this yaw signal that represents the disturbance is 0.1 or 0.05 of a real yaw signal value, since it is only parasite coupling, and it is not of a intensity of a real signal.

The results obtained from time varying autopilot with one value for adjustable parameters are shown (Fig.8).

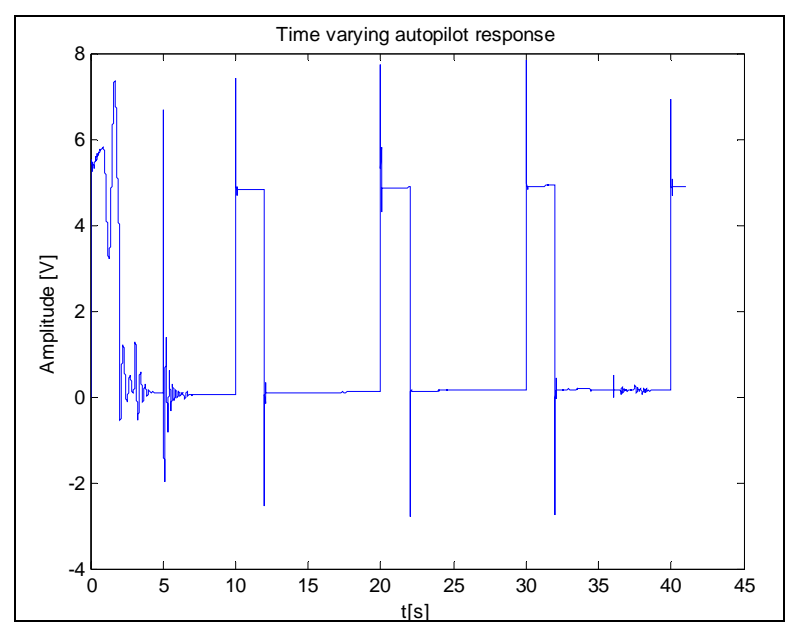

Figure 8. System response time varying autopilot design with cross-coupling type of disturbance 
Afterward, the results obtained from adaptive autopilot design with three different parameters for different flight phases are shown (Fig.9).

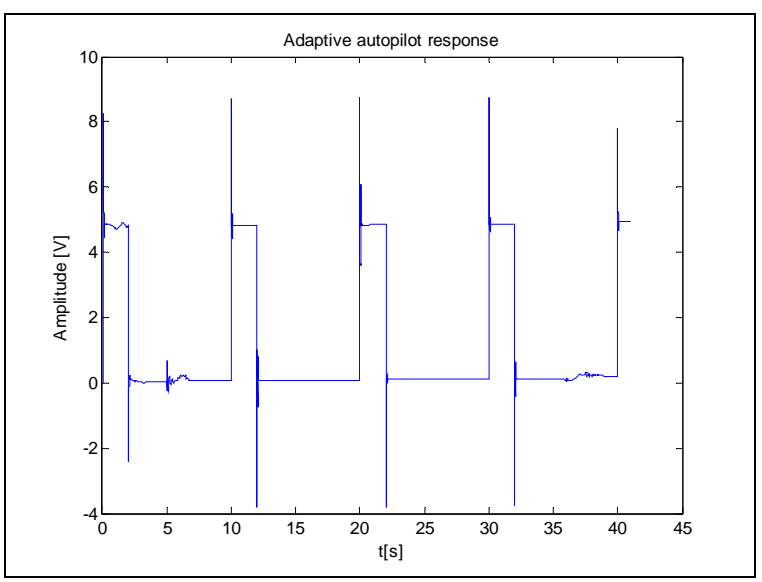

Figure 9. System response time varying autopilot design

As it can be seen from Figures 8 and 9, in the first part of flight, where parameters vary significantly better results can be obtained with adaptive autopilot design, since there is value for this segment that ensures desired system behavior, and another value that ensures desired system behavior for other segments. So, with the adaptive design of this type, accomplishment is that response is more stable at the first time interval. Further on, stationary value is more precise in the constant flight parameter interval, and, in parts with very big parameter changes, there are no so intense oscillations, as was the case with previous non-adaptive design.

\section{Conclusion}

In this paper, an approach to autopilot design is described. It begins with simple model design - constant parameter design with transfer function coefficients that are constant in time. This is first step in design, which is important for the designer to get familiarized with the system. Next described step is more complex model, time varying autopilot design with dynamic coefficients that change over time, therefore all transfer functions need to be represented accordingly. One value for adjustable parameters is calculated, and that value should be optimal for entire time interval. The last step is adaptive autopilot design with different values for the adjustable parameters in for each flight phase. It is shown that adaptive autopilot design gives better performance in all intervals, and stabilizes the moving object in phases with drastic parameter changes. In a case where disturbance of a cross-coupling type is present, different values are used for adjustable coefficients, and the results would be even better with more different values, which will certainly be topic to consider in future work. Further on, it is not always possible to find optimal solution when using linearized model parameters, especially when dealing with highly maneuverable missiles. On the other hand there may be modelling errors and parameter uncertainties. In these cases, nonlinear control design approaches can be really helpful, as described in [7]. Therefore, it can be a topic for future work and autopilot design robustness improvement.

\section{References}

[1] BAILliEUL,J., SAMAD,T.: Encyclopedia of Systems and Control, DOI 10.1007/978-1-4471-5058-9, Springer-Verlag London 2015.

[2] MOHAMMADI,M.R., JEGARKANDI,M.F., MOARREFIANPOUR,A.: Robust roll autopilot design to reduce couplings of a tactical missile, Aerospace Science and Technology, 2016, 51, pp.142-150.

[3] GRAOVAC,S.: Automatic Guidance of Objects in Space, Akademska misao, Belgrade, 2006

[4] GARNELL,P., EAST,D.J.: G uided Weapon Control Systems, Royal Military College of Science, Swindon, England, 1977

[5] ĆUK,D., ĆURČIN,M., MANDIĆ,S.: Autopilot Design, Theoretical Manual, Military Technical Institute (VTI), Belgrade, 2004

[6] ĐUROVIĆ,Ž., KOVAČEVIĆ,B. :Automatic Control Systems, Akademska misao, Belgrade, 2006.

[7] KIM,S.H., KIM,Y.S., SONG,C.: A robust adaptive nonlinear control approach to missile autopilot design, Control Engineering Practice 2004, 12, pp,149-154, doi: 10.1016/S0967/0661(03)00016-9.

Received: 11.04.2016. Accepted: 07.10.2016.

\title{
Dizajn adaptivnog autopilota sa vremenski promenljivim parametrima
}

\begin{abstract}
Autopilot predstavlja sistem za precizno praćenje mete koju je potrebno da pogodi raketa za koju je dizajniran . Zadate komande, koje je potrebno da raketa izvrši, prosleđuju se autopilotu, kako bi se postigla zahtevana performansa sistema. Obično se kod reprezentacije autopilota i njegovih performansi koristi model sa konstantnim parametrima. Proračun autopilota sa konstantnim parametrima, kao i proračun parametara rakete se bazira na vrednostima koje su vremenski promenljive. U ovom radu je prikazan model sa konstantnim parametrima, kao i rezultati za takav tip dizajna. Izračunate vrednosti se zatim koriste kao početne vrednosti za proračun vremenski promenljivog autopilota propinjanja koji se zasniva na podešavanju pojačanja. Pokazano je kako se poništava dejstvo kuplovanja drugih osa, na primer skretanja, i to korišćenjem vremenski promenljivih parametara. Svi modeli su implementirani u Matlab i Simulink programskom paketu.
\end{abstract}




\title{
Проектирование адаптивного автопилота с изменяющимися во времени параметрами
}

\begin{abstract}
Автопилот представляют собой устройство для точного сопровождения цели и мишени, на которые для поражения отправляются ракеты, и для которых он и разработан. Заданные команды, которые должны выполнить ракеты, перенаправляются на автопилот, чтобы добиться требуемых характеристик системы. Как правило, в представлении автопилота и его характеристик, используется модель с постоянными параметрами. Расчёт автопилота с постоянными параметрами, а в том числе и расчёт параметров ракеты основываются на по времени изменчивыми значениями. В данной работе показана модель с постоянными параметрами, а также и результаты, получены для такого типа модели. Эти расчитанные значения затем используются в качестве первоначальных значений для расчётов по времени изменчивых значений автопилота крена, основывающего на регулировке усиления. Здесь показано, как отменена связь сцепления с другой осью, такой как рыскание, с помощью по времени изменчивых параметров. Все модели выполнены в Matlab и Simulink пакетах программного обспечения.
\end{abstract}

Ключевые слова: автопилот, проектирование, адаптивное устройство, адаптивное управление, тангаж, изменяющиеся во времени коэффициенты, сцепление.

\section{Dessin du pilote automatique adaptif aux paramètres variables dans le temps}

\begin{abstract}
Le pilote automatique représente un système pour le suivi précis de cible qui doit être interceptée par la fusée pour laquelle il a été dessiné. Les commandes que la fusée doit exécuter sont transmises au pilote automatique pour réaliser les performances exigées par le système. Lors de la représentation du pilote automatique et de ses performances on utilise d'habitude le modèle aux paramètres constants. Le calcul du pilote automatique aux paramètres constants ainsi que le calcul des paramètres de fusée se base sur les valeurs variables dans le temps. Dans ce papier on a présenté le modèle aux paramètres constants ainsi que les résultats pour ce type de dessin. Les valeurs calculées ont été utilisées ensuite comme les valeurs initiales pour le calcul du pilote automatique variable dans le temps de tangage qui se basait sur le réglage de renforcement. On a démontré comment annuler l'action du couplage des autres axes par exemple chez la déviation et cela en utilisant les paramètres variables dans le temps. Tous les modèles ont été installés dans le progiciel Matlab et Simulink.
\end{abstract}

Mots clés: pilote automatique, conception, dispositif adaptatif, gestion adaptive, tangage, coefficients variables dans le temps, couplage. 